\title{
The Elements Contributing to Tax Evasion in Saudi Arabia
}

\author{
Daniah Tariq Raqaban \\ MSc International accounting and financial management Henely business school, \\ University of Reading. Reading United Kingdom \\ Email: d.t.ragaban@gmail.com
}

\begin{abstract}
:
The Saudi Arabian's vision had uplifted the Saudi economy within a short time span by adopting different strategic legislation. One of the main adaptations by the Saudi government that assess this uplift was through adopting taxation. As a new legislation it was faced a lot of resistance by the citizen, which led to tax evasion. The study had conducted through mean of survey that focused on testing two main hypotheses to see the relationship between two main groups (morality and understanding) to tax evasion. As it showed the hypothesis was supported by the data collected that both the level of morality do plays a massive role in the perception of tax evasion; moreover, that the level of awareness the individuals have is low to medium level when it comes to understanding the tax rules and regulations.
\end{abstract}

Keywords: Elements, Tax Evasion, Saudi Arabia 


\section{Introduction:}

The Saudi Arabian's vision has introduced a new concept and regulation in the country. It opened new markets and new fields that if properly exploited would uplift the country and its economy even further. One of the main legislations that the Saudi government has recently adapted and the focus of this paper is taxation. Taxation is not a new concept in the world; yet, to Saudi citizens, it is considered to be a new phenomenon that the government is applying.

When Zakat, Tax and Customs Authority (ZATCA) first introduced Tax regulation in Saudi Arabia there was a lot of resistance; which was highly expected as per human nature.

Yet the resistances had taken a deeper sense, and individual started to use alternative measures such as tax evasion to avoid paying tax. The research paper focuses in the tax evasion and the elements that led to such act.

The research grouped the elements in to two groups that build the hypothesis around them. The first group the paper focused on is the moral aspect of the individuals and how it affects their decision when it comes to tax evasion. The second group the paper focused on is the elements of understandability of the tax rules and regulation and their effect on committing tax evasion. Throughout the data collected and analyzed from the survey conducted within the region, it had concluded that the elements of the tax evasion do indeed relate directly to the perception of morality and the level of understanding they might have in regards to tax rules and the regulation in general.

\section{Literature Review:}

Tax evasion has become a global pandemic continuously draining government revenue all around the world. It is considered one of the significant issues for tax authorities for several decades. As it has been stated by Popescu, L 4"Tax evasion represents one of the most important economic and social phenomena that all countries in the world are currently facing". The topic of tax evasion is indeed an important topic for tax authorities to try to close the gap as much as possible. 
Many researchers and economists tried to exploit the topic of tax evasion and identify what possible outcomes that best explain the reason behind such act, or even what new legislation could be imposed to close the gap in tax evasion. Taxes are considered a relatively new concept in Saudi Arabia; where it had been first introduced in 2004. However, this study is focusing on tax evasion in the Value Added Ta-x in specific which has been introduced since $2018 .{ }^{1}$

According to ZATCA, "Value Added Tax (or VAT) is an indirect tax imposed on all goods and services that are bought and sold by businesses, with a few exceptions $(\text { ZATCA, 2019) })^{2}$. VAT is applied in more than 160 countries around the world as a reliable source of revenue for state budgets." 2 At first VAT has been imposed at the rate of $5 \%$ of most goods and services, where according to the world bank it had provided the government with SR7.26 billion in revenue from VAT ${ }^{3}$. In 2020 the government as a means of reviving the national economy had tripled the rate to reach the $15 \%$. With this increase, there has been a lot of resentment and resistance from individuals and citizens by this increase.

This study will focus on the factors and elements that might lead the individual to engage in tax evasion in Saudi Arabia. we examine tax evasion from a social and psychological point of view, focusing on the variable and the understandability of the individuals for the important role taxes has on the nation's economy. We will use surveys as a means to measure the behaviors factors that affect tax evasion. Among the behavior factor, we will examine the complexity and understandability of the tax regulation, moral behavior, and the perception of fairness, and economical aspects of individuals. After careful consideration, we were able to join the elements into two groups, moral behavior on the individualism and complexity and understandability of tax regulation

\subsection{Moral behavior}

Under this element, we are combining both moral behaviors toward tax evasion along with the perception that might the individuals develop toward the tax policies and regulation (the fairness of the VAT system or the lack of services provided in return) that could lead to evading tax. The norms and morality of the individuals play a significant role in the perception the individual may uphold, which should never be taken for granted 5 . 
Different studies conducted within the same elements had reached the same conclusion concerning the positive relationship the tax evasion and perception of justice (Latina and Palivos $)^{6}$ and the extent of tax evasion the individuals my willingly reach to evades (Nicolin D) ${ }^{7}$. Last but not least Alzubi, K, had summaries the most crucial point when it comes to morality; that the stronger the ethical factors and moral behavior the individual holds the more compliance they will be toward taxes from the perspective of income taxes

\subsection{Complexity and Understandability of Tax Regulation}

Tax regulation and tax guides' existence are the ones of taxpayers' right, yet the simplicity of such guidance that allows the tax payer to fully understand the rules and legislation that guides hold. In this study, we try to explore the understandability of tax guidance and the accessibility of such guidance to all individuals, and the extent of following the guidelines.

According to Ali, Ahmed, and Abdul Hamid, one of the main motivations for tax evasion is the lack of proper legislation and the loopholes that individuals might exploit. Which has been reached by Dr. ilyess, $G^{(9)}$ Also, the absence the awareness individuals have toward tax and the importance of it to the national economy does lead to evasion to $\operatorname{tax}^{8}$. Whereas both Nicoline $\mathrm{D}^{10}$ and Almansour had argued that the complexity and tightness of regulation make it difficult to effectively follow it and boost evasion of tax

Based on the above literature, we developed the following hypotheses below to examine the reason for tax evasion in Saudi Arabia:

H1: The level of morality and perception of fairness in the individual norm play an important role in tax evasion

H2: The complexity of regulation or the lack of individual knowledge toward the importance of the VAT on the national economy.

\section{Results and Discussions}

\subsection{Introduction}

This research is a descriptive research, as it was mentioned in the methodology (first chapter); the main research objective is to show the elements of the tax evasion do indeed 
relate directly to the perception of morality and the level of understanding that they might have in regards to tax rules and the regulation in general in Saudi Arabia. Based on examining only a portion of the total population, selected in a way that reflects the structure of the whole. In achieving objectives through this research, the researcher employed the questionnaire survey - as a means of gathering information. This suggests that attitudes are mental positions that cannot be observed directly, but must be analyzed based on research results. The fact that attitudes are learned affirms they will be affected by information and experience.

Moreover, this part aims at analyzing the data that was collected from the research sample, testing the hypotheses, and reaching the results. The research is designed to combine both theoretical and empirical studies using different measures in measuring the variables included in the research hypotheses according to the types of the variables.

Quantitative data was gathered also through the use of questionnaires (close-ended questions), administered during intercepts.

The questionnaire was designed to collect information on Leoni Wiring Systems Organization to explore about the opinion, views, contributions and variables and studying the elements of the tax evasion do indeed relate directly to the perception of morality and the level of understanding that they might have in regards to tax rules and the regulation in general in Saudi Arabia where a survey questionnaire will be used to collect the required data. The level of scale was interval and the technique was five point Likert type scale at the numeral 1 with the verbal statement 'strongly disagree' and at the numeral 5 with the verbal statement 'strongly agree'.

The Researcher was keen after the completion of data collection in every single of sample to review these data in every form, in order to ensure the completeness of data, and the veracity of the information, and to check the rate of yield to these forms and the wastage in the data. After the completion of the review of the final form, The Researcher moved to a new stage, It is converting the raw data into numbers to be handled statistically, To achieve that, 
The researcher used the manual coding to convert large quantities of raw data in the form of a questionnaire to shortlist data to fit the dump data and the statistical analysis process later. Preliminary data have been received in the form converted to digital codes in the manual coding, According to the rules and standards of the units of measurement that have been developed to measure the variables properties that involved in the study .

The answers to each paragraph was in accordance with the Fifth Likert Scale as follows:

\begin{tabular}{|l|c|c|c|c|c|}
\hline The Category & $\begin{array}{c}\text { Strongly } \\
\text { agree }\end{array}$ & Agree & Neutral & Disagree & $\begin{array}{c}\text { Strongly } \\
\text { Disagree }\end{array}$ \\
\hline Degree & 5 & 4 & 3 & 2 & 1 \\
\hline
\end{tabular}

After the completion of phase of encoding data in which the transfer of this data from its qualitative form to quantitative form, Then this data has transferred the amount allocated to discharge cards. Therefore, according to the previous rules Serial numbers has to interview forms to reflect every single of forms of single of the vocabulary of the research community.

\subsection{Data and Methodology}

The collected data has been summarized in a table format in the Excel file. Additionally, the data has also been placed in an SPSS file format for analysis. In Excel, the variable format is in words, while SPSS variable formats are in numbers (Okagbue et al., 2021). The data will be analyzed through different statistical methods that best analyze and measure the date at hand. The total number of participants for the study was 63 . However, only 61 participants provided complete data. Hence, the data of 2 participants were excluded from the study.

\subsection{Research Limitation}

The study recognizes several limitations such as

1. This study population is in Saudi Arabia.

2. There are some limitations in the amount of information. It will obtain from daily life. 


\subsection{Statistical Methods are used :}

The researcher in conducting statistical analyzes on the Statistical Package for the hypotheses as to rely on the following statistical methods program :-( SPSS) win, which depends on the following statistical methods

This chapter presents the empirical study conducted in Saudi Arabia. The chapter statistically analyzes the data gathered from the research sample, using the statistical program for Social Science (SPSS). The statistical analysis techniques include the following:

1. Cronbach's Alpha to test the reliability of questionnaire that used

2. Correlation Coefficients to test the factor analysis of questionnaire that used

3. Kolmogorov-Smirnov analysis to test normality of distribution

4. Descriptive statistics for all main variables and their dimensions.

5. Pearson Correlation Coefficients analysis to test the correlation among the study variables

6. One sample t-test to test the difference among the study variables

7. ONE WAY ANOVA Test to test the difference among the study variables

It is worthy to mention that an alpha level of 0.05 was used for all statistical tests.

\subsection{Measurement Model Assessment}

This section of the study explains the procedures that the researcher has undertaken to examine the validity and reliability of the constructs. As for examining the validity, an exploratory factor analysis has been conducted on SPSS 26 to account for construct validity. For examining reliability, Cronbach's alpha has been extracted to evaluate the internal consistency of the measures that have been adopted for the purposes of this study.

\subsection{Kolmogorov-Smirnov Test}

The researcher used Kolmogorov-Smirnov to test normality of distribution also to check if the model follows the normal distribution or not as below: 
Table (1) Show normality test by using Kolmogorov-Smirnov for the research model

\begin{tabular}{|l|c|c|l|}
\hline \multicolumn{1}{|c|}{ Research Variables } & $\begin{array}{c}\text { Kolmogorov- } \\
\text { Smirnov }\end{array}$ & *Sig. & \multicolumn{1}{|c|}{ Results } \\
\hline The average of research variables & .114 & .001 & $\begin{array}{l}\text { Follow } \\
\text { Normal } \\
\text { distribution }\end{array}$ \\
\hline
\end{tabular}

* If the value of Sig is less than 0.05 model will follow the normal distribution

The above table shows Kolmogorov-Smirnov to test the normality distribution of the model and as noticed the value of sig. for Kolmogorov-Smirnov test was less than 0.05 and it means that the research model follows the normal distribution

\subsection{Reliability Analysis}

Reliability means that a measure or questionnaire should consistently reflect the construct that it is measuring ${ }^{(1)}$. Reliability is used to measure the same scale items multiple times, ensuring that the same result is found every time, as long as the underlying phenomenon is not changing. Reliability is also a measure of internal consistency between different items of the same construct. When a multiple-item scale is provided to respondents, and yield similar score every time even if it is completed at two different points in time, this is a reflection of internal consistency. Therefore, it can be said that reliability can be estimated in terms of average inter-item correlation, average item-to-total correlation, or more commonly, Cronbach's alpha ${ }^{(2)}$. In this study, reliability of each scale has been tested through Cronbach's alpha to identify the internal consistency of the scale .

The alpha coefficient value depends on the number of items on the scale. In general, reliabilities less than 0.6 are considered poor, the 0.7 range, accepted, and over 0.8 good $^{(3)}$

$\left.{ }^{1}\right)$ Field, A. (2009). Discovering Statistics Using SPSS: Introducing Statistical Method (3rd ed.). Thousand Oaks, CA: Sage Publications.

$\left({ }^{2}\right)$ Bhattacherjee, A. (2012). Social science research: principles, methods, and practices.

${ }^{3}$ ) Sekaran, U. (2003). Research Methods for Business: A skill Building Approach. New York: Wiley. 
In a reliable scale all items should correlate with the total. So, if items don't correlate with the overall score from the scale with their values being less than about 0.3 it means there are problems, as a particular item does not correlate very well with the scale overall.

Items with low correlations may have to be dropped ${ }^{(4)}$. For the data in this study, all data have item-total correlations above

The following table summarizes the reliability test results for the study variables. All of the variables show an alpha coefficient of more than 0.6.

Table (2) Reliability Analysis for Research Variables

\begin{tabular}{|c|c|}
\hline \multicolumn{1}{|c|}{ Variables } & Cronbach's Alpha \\
\hline The main average of the research model & .866 \\
\hline
\end{tabular}

The results indicate that the research variables are measuring in the organization and It is intended to stabilize the scale and lack of contradiction with himself, he saw that it gives the same results if re-applied to the same sample and test stability using Cronbach alpha coefficient. the Cronbach alpha for the research model was 0.866. The coefficient of consistency takes values ranging between zero and the right one, if there was no data on the stability of the value of this parameter equal to zero, and vice versa, where if there is a complete firming be the parameter value equal to the correct one. And therefore the closer the value of reliability coefficient of the correct one indicates that the Stability high

\subsection{Descriptive Analysis}

Reporting descriptive statistics so that the researcher is familiar with the data and understands the relationships between variables. In summary, a descriptive analysis of respondent profile in terms of gender and age have been presented. Summary statistics of the Frequencies, Percentages, Mean and Standard deviation for each of the variables in the model are reported in this section.

( ${ }^{4}$ ) Field, A. (2009). Discovering Statistics Using SPSS: Introducing Statistical Method (3rd ed.). Thousand Oaks, CA: Sage Publications. 
Academic Journal of Research and Scientific Publishing | Vol 3 | Issue 32

Publication Date: 5-12-2021 ISSN: 2706-6495

\subsubsection{Frequencies and Percentages}

Table (3) shows the descriptive statistics for the research demographic data

\begin{tabular}{|l|l|l|c|c|}
\hline No. & Variable name & Label & Frequencies & Percentages \\
\hline $\mathbf{1}$ & \multirow{2}{*}{ Gender } & Male & 24 & 39.3 \\
\cline { 3 - 5 } & & Female & 37 & 60.7 \\
\hline $\mathbf{2}$ & Age & From 18 to 24 years & 1 & 1.6 \\
\cline { 3 - 5 } & & From 25 to 34 years & 15 & 24.6 \\
\cline { 3 - 5 } & \multirow{3}{*}{$\mathbf{3}$} & From 35 to 45 years & 25 & 41.0 \\
\cline { 3 - 5 } & & More than 45 years & 20 & 32.8 \\
\cline { 3 - 5 } & & From 3000 to 4999 & 10 & 16.4 \\
\cline { 3 - 5 } & & From 5000 to 9999 & 11 & 18.0 \\
\cline { 3 - 5 } & & From 10000 to14999 & 6 & 9.8 \\
\cline { 3 - 5 } & From 15000 to 19999 & 13 & 21.3 \\
\cline { 3 - 5 } & & More than 20000 & 21 & 34.4 \\
\hline
\end{tabular}

The above table shows the descriptive statistics for the research demographic data and the researcher concluded that:

\section{For Gender variable}

The researcher found that the total sample Males were 24 samples and the total sample of Females were 37 samples, giving a total of 61 respondents in Saudi Arabia as shown in the below figure.

Figure (1) gender

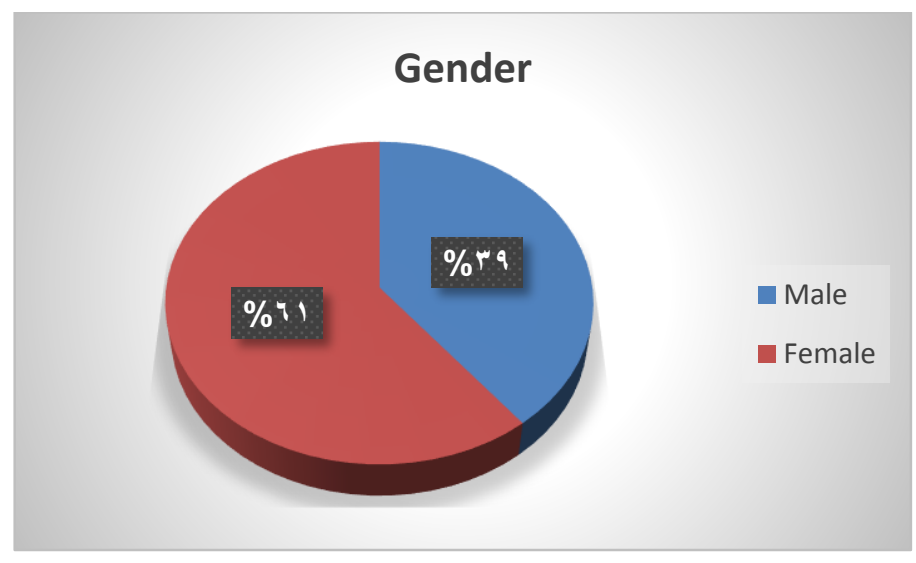




\section{For age variable}

The researcher found that the total sample of who are in age interval "From 18 to 24 years" was one sample, The researcher found that the total sample of who are in age interval "From 25 to 34 years" were 15 samples, The researcher found that the total sample of who are in age interval "From 35 to 45 years" were 25 samples, while The researcher found that the total sample of who are in age interval "More than 45 years" were 20 samples, giving a total of 61 respondents in Saudi Arabia as shown in the below figure.

\section{Figure (2) Age Range}

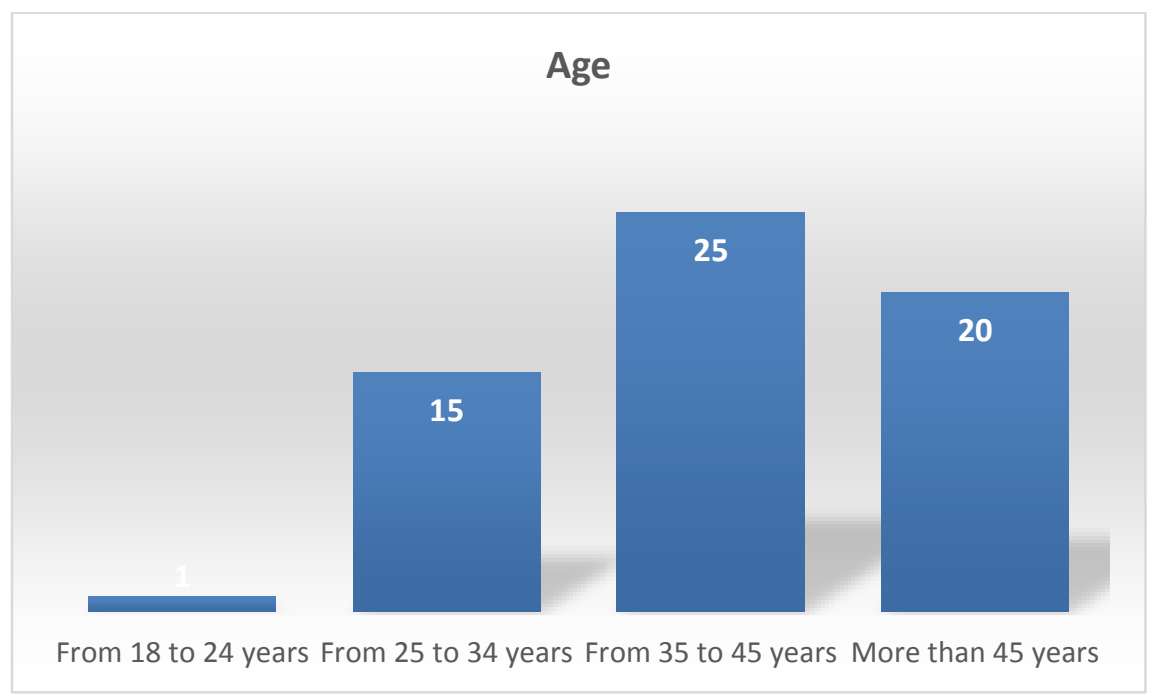

\section{For Income variable}

The researcher found that the total sample of who have "From 3000 to 4999 " were 10 samples, The researcher found that the total sample of who have "From 5000 to 9999" were 11 samples, The researcher found that the total sample of who have "From 10000 to14999" were 6 samples, The researcher found that the total sample of who have "From 15000 to 19999 " were 13 samples, while The researcher found that the total sample of who have "More than 20000" were 21 samples, giving a total of 61 respondents in Saudi Arabia as shown in the below figure. 
Figure (3) Income Range

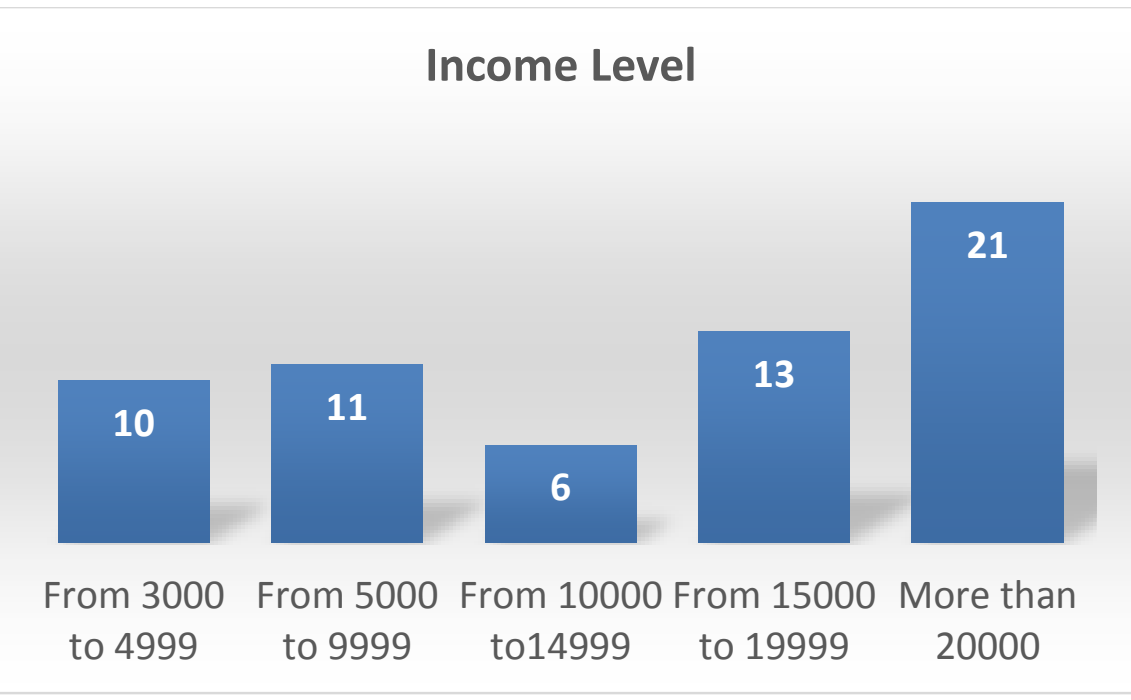

\section{How familiar are you with tax law?}

Table (4) shows the descriptive statistics for "How familiar are you with tax law?" Variable

\begin{tabular}{l|r|r|r} 
& $\begin{array}{c}\text { Frequenc } \\
\text { y }\end{array}$ & Percent & \multicolumn{1}{c}{$\begin{array}{c}\text { Cumulative } \\
\text { Percent }\end{array}$} \\
\hline No clue & 10 & 16.4 & 16.4 \\
\hline Low level & 23 & 37.7 & 54.1 \\
\hline Mid-level & 22 & 36.1 & 90.2 \\
\hline High level & 6 & 9.8 & 100.0 \\
\hline Total & 61 & 100.0 & \\
\hline
\end{tabular}

The above table shows the descriptive statistics for "How familiar are you with tax law?" variable and the researcher concluded that who chose No clue were 10 samples, who chose Low level were 23 samples, who chose Mid-level were 22 samples, while who chose High level were 6 samples, giving a total of 61 respondents in Saudi Arabia as shown in the below figure. 
Figure (4) how familiar are you with tax law?

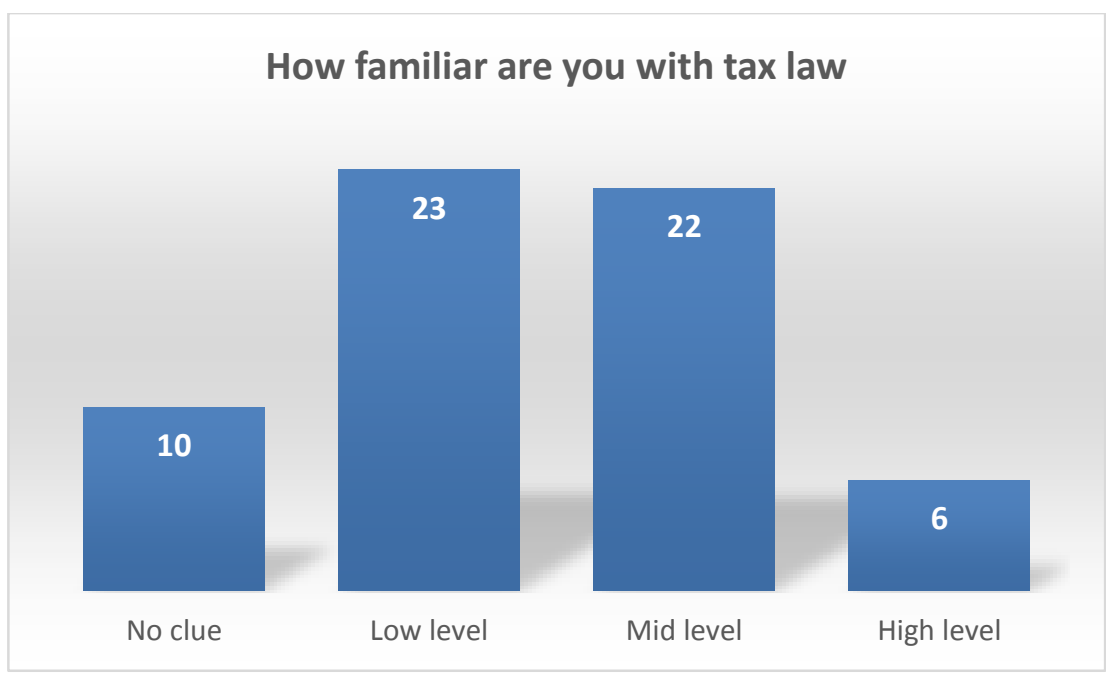

\section{Have you attended introductory meetings or seminars on the implementation of value added tax?}

Table (5) shows the descriptive statistics for "Have you attended introductory meetings or seminars on the implementation of value added tax?" Variable

\begin{tabular}{lr|r|r} 
& $\begin{array}{c}\text { Frequenc } \\
\text { y }\end{array}$ & Percent & \multicolumn{1}{c}{\begin{tabular}{c} 
Percent \\
\hline No
\end{tabular}} \\
\hline Yes & 48 & 78.7 & 78.7 \\
\hline Total & 13 & 21.3 & 100.0 \\
\hline
\end{tabular}

The above table shows the descriptive statistics for "Have you attended introductory meetings or seminars on the implementation of value added tax?" variable and the researcher concluded that who chose No were 48 samples while who chose Yes were 13 samples, giving a total of 61 respondents in Saudi Arabia as shown in the below figure. 
Figure (6) Have you attended seminars or meeting in value added tax?

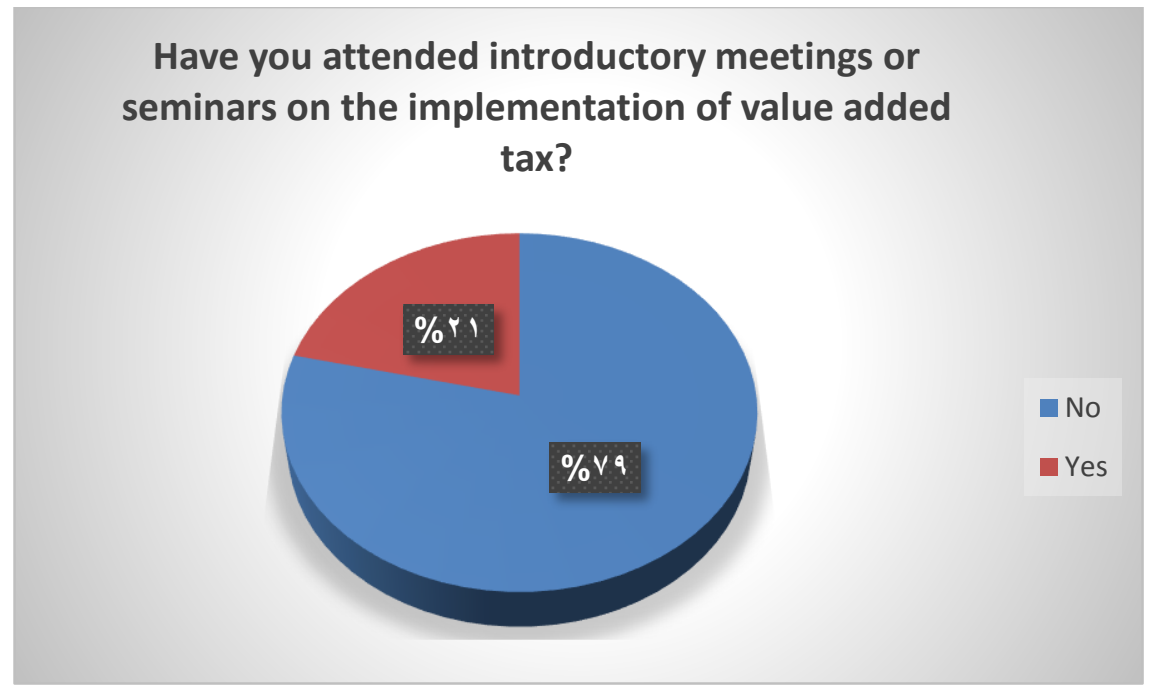

\section{How many introductory meetings or seminars that you attended on the}

\section{implementation of value added tax?}

Table (6) shows the descriptive statistics for "How many introductory meetings or seminars that you attended on the implementation of value added tax?" Variable

\begin{tabular}{|c|c|c|c|}
\hline & $\begin{array}{c}\text { Frequenc } \\
\mathrm{y}\end{array}$ & Percent & $\begin{array}{c}\text { Cumulative } \\
\text { Percent }\end{array}$ \\
\hline $\mathrm{No}$ & 48 & 78.7 & 78.7 \\
\hline 1.00 & 5 & 8.2 & 86.9 \\
\hline 2.00 & 3 & 4.9 & 91.8 \\
\hline 3.00 & 2 & 3.3 & 95.1 \\
\hline 4.00 & 1 & 1.6 & 96.7 \\
\hline 10.00 & 1 & 1.6 & 98.4 \\
\hline 15.00 & 1 & 1.6 & 100.0 \\
\hline Total & 61 & 100.0 & \\
\hline
\end{tabular}

The above table shows the descriptive statistics for "How many introductory meetings or seminars that you attended on the implementation of value added tax?" variable and the researcher concluded that who chose one introductory meetings or seminars were 5 samples, who chose 2 introductory meetings or seminars were 3 samples, 
While who chose 3 introductory meetings or seminars were 2 samples, giving a total of 61 respondents in Saudi Arabia as shown in the below figure.

Figure (7) how many seminars have you attend?

\section{How many introductory meetings or seminars that you attended on the implementation of value added tax?}

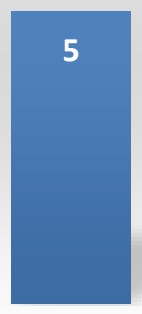

1

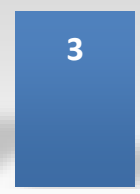

\section{2}

\section{1}

$\varepsilon$

\section{1}

1.

\section{1}

10

\section{6- Do you support the tax law?}

Table (7) shows the descriptive statistics for "Do you support the tax law?" Variable

\begin{tabular}{l|r|r|r} 
& $\begin{array}{r}\text { Frequenc } \\
\text { y }\end{array}$ & Percent & \multicolumn{1}{c|}{$\begin{array}{c}\text { Pumulative } \\
\text { Percent }\end{array}$} \\
\hline No & 42 & 68.9 & 68.9 \\
\hline Yes & 19 & 31.1 & 100.0 \\
\hline Total & 61 & 100.0 & \\
\hline
\end{tabular}

The above table shows the descriptive statistics for "Do you support the tax law?" variable and the researcher concluded that who chose No were 42 samples, while who chose Yes were 19 samples, giving a total of 61 respondents in Saudi Arabia as shown in the below figure. 
Figure (8) Do you support tax law?

Do you support the tax law?

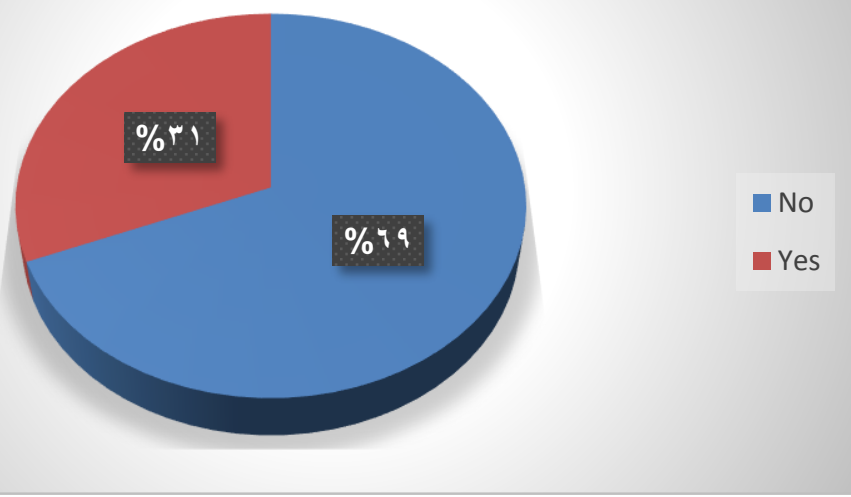

\subsubsection{Mean and Std and Relative Importance}

Table (8) shows Mean and Std and Relative Importance for the research model

\begin{tabular}{|c|l|c|c|c|c|}
\hline No & \multicolumn{1}{|c|}{ Statement } & Mean & $\begin{array}{c}\text { Std. } \\
\text { Deviation }\end{array}$ & $\begin{array}{c}\text { Relative } \\
\text { Importance }\end{array}$ & Rank \\
\hline 7 & 7 High rate of added tax & 3.36 & 1.56 & 67.21 & 5 \\
\hline 8 & $\begin{array}{l}\text { Feeling of not getting services for the } \\
\text { value of the tax }\end{array}$ & 3.92 & 1.27 & 78.36 & 1 \\
\hline 9 & Seller's low economic status & 3.59 & 1.22 & 71.80 & 3 \\
\hline 10 & $\begin{array}{l}\text { Laws and regulations related to the value } \\
\text { added tax }\end{array}$ & 3.08 & 0.97 & 61.64 & 6 \\
\hline 11 & $\begin{array}{l}\text { The absence of tax awareness and its } \\
\text { benefit to the state for the seller }\end{array}$ & 3.61 & 1.20 & 72.13 & 2 \\
\hline 12 & $\begin{array}{l}\text { the high prices of government } \\
\text { transactions }\end{array}$ & 3.51 & 1.12 & 70.16 & 4 \\
\hline 13 & $\begin{array}{l}\text { Difficulty in procedures of government } \\
\text { transactions }\end{array}$ & 2.95 & 1.40 & 59.02 & 9 \\
\hline
\end{tabular}




\begin{tabular}{|l|l|c|c|c|c|}
\hline No & \multicolumn{1}{|c|}{ Statement } & Mean & $\begin{array}{c}\text { Std. } \\
\text { Deviation }\end{array}$ & $\begin{array}{c}\text { Relative } \\
\text { Importance }\end{array}$ & Rank \\
\hline 14 & $\begin{array}{l}\text { There is nothing wrong with the process } \\
\text { of tax evasion as long as the value of tax } \\
\text { evasion is minimal }\end{array}$ & 1.69 & 1.06 & 33.77 & 11 \\
\hline 15 & $\begin{array}{l}\text { There is nothing wrong with tax evasion } \\
\text { if the evasion is by using legal loopholes } \\
\text { in the system }\end{array}$ & 2.31 & 1.47 & 46.23 & 10 \\
\hline 16 & $\begin{array}{l}\text { I don't mind dispensing with the bill in } \\
\text { return for the 15\% VAT deduction }\end{array}$ & 3.07 & 1.41 & 61.31 & 8 \\
\hline 17 & $\begin{array}{l}\text { 9. Have you ever been in a situation } \\
\text { where you have resorted to tax evasion? }\end{array}$ & 3.08 & 1.28 & 61.64 & 7 \\
\hline & $\begin{array}{l}\text { The main average of the research } \\
\text { model }\end{array}$ & $\mathbf{2 . 9 2}$ & $\mathbf{0 . 5 4}$ & $\mathbf{5 8 . 3 1}$ & \\
\hline
\end{tabular}

According to the previous table, it can be concluded that:

The relative importance of the element "Feeling of not getting services for the value of the tax" is $78.36 \%$ and its mean is 3.92 while its standard deviation is 1.27 , comes at the first rank and the relative importance of the element "The absence of tax awareness and its benefit to the state for the seller" is $72.13 \%$ and its mean is 3.61 while its standard deviation is 1.2 , comes at the second rank while the relative importance of the element "There is nothing wrong with the process of tax evasion as long as the value of tax evasion is minimal" is $33.77 \%$ and its mean is 1.69 while its standard deviation is 1.06 , comes at the last rank

The relative importance of the whole model is $58.31 \%$ and its mean is 2.92 while its standard deviation is 0.54

\section{Do you think that with the country's economy recovering, the value-added tax} should? 
Table (9) shows the descriptive statistics for "Do you think that with the country's economy recovering, the value-added tax should?" Variable

\begin{tabular}{l|r|r|r} 
& $\begin{array}{c}\text { Frequenc } \\
\text { y }\end{array}$ & Percent & \multicolumn{1}{c}{\begin{tabular}{c} 
Percent \\
\hline stay as is
\end{tabular}} \\
\hline decreases by small amount & 26 & 1.6 & 1.6 \\
\hline CANCELED & 34 & 55.7 & 100.0 \\
\hline Total & 61 & 100.0 & \\
\hline
\end{tabular}

The above table shows the descriptive statistics for "Do you think that with the country's economy recovering, the value-added tax should?" variable and the researcher concluded that who chose economy will stay as it is was only one sample, who chose decreases by small amount were 26 samples, while who chose Cancelled were 34 samples giving a total of 61 respondents in Saudi Arabia as shown in the below figure.

Figure (9) Do you think that with the country's economy recovering, the value-added tax should?

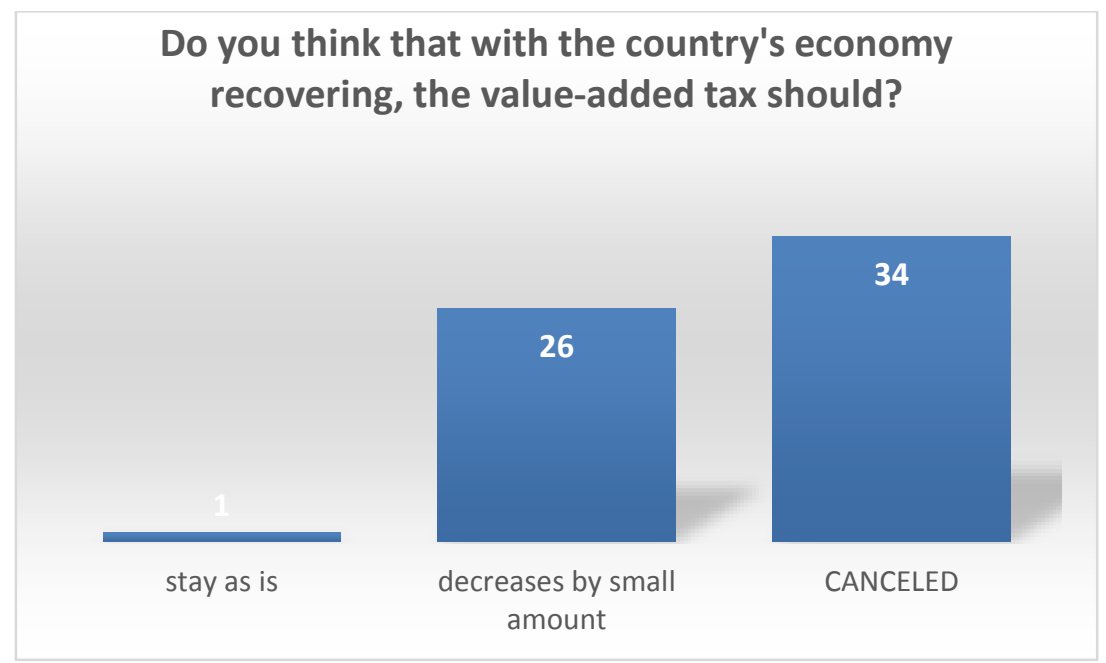




\subsubsection{One-Sample t-test}

Table (10) One-Sample Statistics

\begin{tabular}{|c|c|c|c|c|}
\hline & $\mathrm{N}$ & Mean & Std. Deviation & Std. Error Mean \\
\hline $\begin{array}{l}\text { How familiar are you with } \\
\text { tax law? } \\
\text { Laws and regulations } \\
\text { related to the value added } \\
\text { tax } \\
\text { The absence of tax } \\
\text { awareness and its benefit to } \\
\text { the state for the seller } \\
\text { the high prices of } \\
\text { government transactions } \\
\text { Difficulty in procedures of } \\
\text { government transactions } \\
\text { Do you think that with the } \\
\text { country's economy } \\
\text { recovering, the value-added } \\
\text { tax should? }\end{array}$ & $\begin{array}{l}61 \\
61 \\
61\end{array}$ & $\begin{array}{l}2.61 \\
3.08 \\
\\
3.61 \\
\\
3.51 \\
2.95 \\
2.54\end{array}$ & $\begin{array}{r}.881 \\
.971 \\
1.201 \\
1.120 \\
1.396 \\
.535\end{array}$ & $\begin{array}{r}.113 \\
.124 \\
.154 \\
.143 \\
.179 \\
.068\end{array}$ \\
\hline
\end{tabular}

A one-sample t-test is used to establish whether the mean of a given population is equal to a given value. It can also generate descriptive values (Ross \& Willson, 2017). The selected variables range from "strongly disagree" to "strongly agree," with values from 1 to 5, respectively. Since 3 represented a neutral opinion, it was used as the test value. Any value below 3 indicates a disagreement with the variable. Values greater than 3 show an agreement with the variable. Table 6 provides the mean value of the selected groups. "How familiar are you with tax law?" has a mean of 2.61. The values range from 1 to 4 , which represents "high level" to "no clue," respectively. That shows that the majority of the participants have mid-level to low-level knowledge regarding tax law. 
Table (11) One-Sample t-test

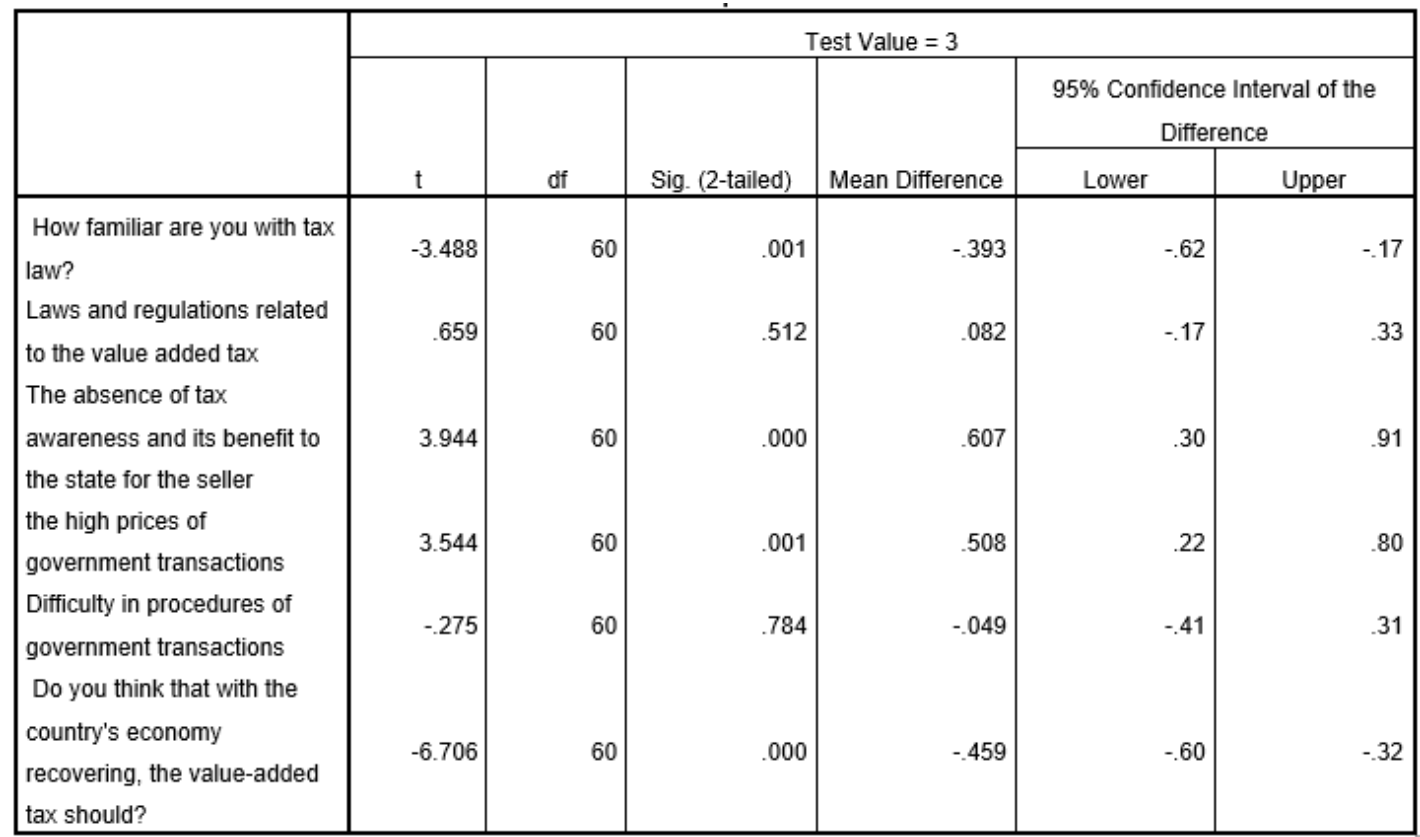

The variables "laws and regulations related to value-added tax" and "absence of tax awareness and its benefit to seller" have means of 3.08 and 3.61 respectively. Since the values of 1-4 representing "strongly disagree" and "strongly agree," the participants agree with these statements. The variable "high prices of government transactions" has a mean of 3.51, which shows that participants agree that the government transactions are high. Lastly, the variables "difficulty in procedures of government transactions" and "do you think that value-added tax should?" have means of 2.95 and 2.54 respectively. More participants are in a neutral position when it comes to the difficulty of conducting government transactions. The bottom variable has values ranging from 1 to 3 , which represents "canceled," "decrease a little," and "stay as it is". Since the mean is 2.54 , most of the respondents believe that the tax value should be slightly decreased.

Table (12) One-sample statistics for meeting attendance

\begin{tabular}{|c|c|c|c|c|}
\hline & & & & \\
\hline & $\mathrm{N}$ & Mean & Std. Deviation & Std. Error Mean \\
\hline $\begin{array}{l}\text { Have you attended } \\
\text { introductory meetings or } \\
\text { semenars on the } \\
\text { implementation of value } \\
\text { addedtax? }\end{array}$ & 61 & 1.95 & .284 & .036 \\
\hline
\end{tabular}


The above table shows that the mean of participants attending seminars on tax implementation is 1.95. Herein, 1 represents "yes," and 2 stands for "no." The mean of 1.95 signifies that the majority of the participants did not attend seminars on tax implementation.

Thus, the $\mathrm{H} 2$ that implies that the complexity of regulation or the lack of individual knowledge toward the importance of the VAT on the national economy is supported. That is because the participants have a moderate to low level of awareness concerning tax law. Moreover, almost all the participants have not attended any tax implementation seminars.

\subsubsection{One-way ANOVA}

In one-way ANOVA, morality is compared with tax evasion. Furthermore, one-way ANOVA is used to compare the means of three or more groups (Kaltenbach, 2021). As shown in the below table:-

Table (13) Descriptive ANOVA

\begin{tabular}{|c|c|c|c|c|c|c|c|}
\hline & & \multicolumn{6}{|c|}{ Docoriptivo } \\
\hline & & \multirow[b]{2}{*}{$\mathbb{N}$} & \multirow[b]{2}{*}{ Mean } & \multirow[b]{2}{*}{ Std. Deviation } & \multirow[b]{2}{*}{ sod. Error } & \multicolumn{2}{|c|}{$\begin{array}{l}\text { gass Confidence Inberval } \\
\text { for Mean }\end{array}$} \\
\hline & & & & & & Lower Bound & $\begin{array}{l}\text { Upper } \\
\text { Bound }\end{array}$ \\
\hline \multirow{6}{*}{$\begin{array}{l}\text { not having govemnemal } \\
\text { services for the VAT taken }\end{array}$} & stronaly disoporee & 27 & 3.33 & 1.519 & .292 & 273 & 3.93 \\
\hline & Disegree & 11 & 4.27 & -786 & .237 & 3.74 & 4. $\mathrm{ac}$ \\
\hline & neutral & 8 & 3.88 & 835 & .295 & 3.18 & 4.57 \\
\hline & agree & 7 & 4.71 & 756 & .286 & 4.02 & 5.41 \\
\hline & stronaly agree & 8 & 4.75 & 463 & .164 & 436 & 5.14 \\
\hline & Totol & 61 & 392 & 1.269 & .162 & 3.59 & 4.24 \\
\hline \multirow{6}{*}{$\begin{array}{l}\text { the eoanomic bandtion for the } \\
\text { VAT payee }\end{array}$} & stronaly disopree & 27 & 307 & 1.238 & $.23 a$ & 258 & 3.56 \\
\hline & Disogree & 11 & 400 & 1.044 & .315 & 3.39 & 4.75 \\
\hline & neutral & 8 & 388 & 835 & .296 & 3.18 & 4.57 \\
\hline & agree & 7 & 3.86 & 1.215 & .459 & 273 & $4.9 \mathrm{e}$ \\
\hline & strongly agree & 8 & 4.13 & 1.246 & .441 & 308 & 5.17 \\
\hline & Totol & 61 & 3.50 & 1216 & 156 & 328 & 3.90 \\
\hline \multirow{6}{*}{$\begin{array}{l}\text { Leot mind GsocaciRa, the bil in } \\
\text { return for } 15 \% \text { VAT deduction } \\
\text { in the amoum }\end{array}$} & strongly disogree & 27 & 244 & 1368 & .263 & 1.90 & 2.99 \\
\hline & Disepree & 11 & 264 & 1.027 & .310 & 195 & 3.33 \\
\hline & neutral & 8 & 325 & ses & .313 & 251 & 3.99 \\
\hline & agree & 7 & 4. 14 & 1.069 & .404 & 3.15 & 5.13 \\
\hline & stronaly agree & 8 & 463 & 1.061 & .375 & 3.74 & 5.51 \\
\hline & Total & E1 & 3.07 & 1.413 & .181 & 270 & 3.43 \\
\hline \multirow[t]{6}{*}{ Do you support the tax law } & strongly disogree & 27 & 200 & $\infty \infty$ & .000 & 200 & 2.00 \\
\hline & Disepree & 11 & 200 & $\infty \infty$ & .000 & 200 & 2.00 \\
\hline & neutral & 8 & 200 & $\infty \infty$ & .000 & 200 & 2.00 \\
\hline & agree & 7 & 200 & $\infty \infty$ & .000 & 200 & 2.00 \\
\hline & stronaly agree & s & 200 &.$\infty 00$ & .000 & 200 & 2.00 \\
\hline & Total & E1 & 200 & .000 & .000 & 200 & 2.00 \\
\hline \multirow{6}{*}{$\begin{array}{l}\text { Have you ever been in a } \\
\text { situation where you hove } \\
\text { resorted bo tax evasion }\end{array}$} & stronaly disoporee & 27 & 200 & .000 & .000 & 200 & 2.00 \\
\hline & Disooree & 11 & 200 & $\infty \infty$ & .000 & 200 & 2.00 \\
\hline & neutral & 8 & 200 & $\infty \infty 0$ & .000 & 200 & 2.00 \\
\hline & aaree & 7 & 200 & $\infty \infty 0$ & .000 & 200 & 2.00 \\
\hline & strongly agree & s & 200 & .000 & .000 & 200 & 2.00 \\
\hline & Totol & 61 & 200 & .000 & .000 & 200 & 2.00 \\
\hline
\end{tabular}


The above table shows the descriptive values for selected variables. The variable "have you ever committed tax evasion" has a mean value of 2 . In this variable, 1 represents "yes," while 2 represents "no". The result shows that all the participants did not commit tax evasion. Additionally, the variable "do you support tax law?" has an average of 2. Therefore, all respondents supported tax law. The rest of the variables have means of 3.92, 3.59, and 3.07, which shows that the participants slightly agree with the statements of "not having governmental services for VAT taken," "the economic condition for VAT payee," and "I don't mind dispensing the bill for $15 \%$ deduction".

Table (14) ANOVA

\begin{tabular}{|c|c|c|c|c|c|c|}
\hline \multicolumn{7}{|c|}{ A } \\
\hline & & Sum of Squares & $\mathrm{df}$ & Mean Square & $\mathrm{F}$ & Siq. \\
\hline \multirow{3}{*}{$\begin{array}{l}\text { not having governmental } \\
\text { services for the VAT taken }\end{array}$} & Between Groups & 20.605 & 4 & \multirow{3}{*}{$\begin{array}{l}5.151 \\
1.357\end{array}$} & \multirow[t]{3}{*}{3.796} & \multirow[t]{3}{*}{.008} \\
\hline & Within Groups & 75.985 & 56 & & & \\
\hline & Total & 96.590 & 60 & & & \\
\hline \multirow{3}{*}{$\begin{array}{l}\text { the economic condition for } \\
\text { the VAT payee }\end{array}$} & Between Groups & 13.386 & 4 & \multirow{3}{*}{$\begin{array}{l}3.347 \\
1.346\end{array}$} & \multirow[t]{3}{*}{2.487} & \multirow[t]{3}{*}{.054} \\
\hline & Within Groups & 75.368 & 56 & & & \\
\hline & Total & 88.754 & 60 & & & \\
\hline \multirow{3}{*}{$\begin{array}{l}\text { i dont mind dispercing the bill } \\
\text { in return for } 15 \% \text { VAT } \\
\text { deduction in the amount }\end{array}$} & Between Groups & 40.293 & 4 & \multirow{3}{*}{$\begin{array}{r}10.073 \\
1.419\end{array}$} & \multirow[t]{3}{*}{7.101} & \multirow[t]{3}{*}{.000} \\
\hline & Within Groups & 79.444 & 56 & & & \\
\hline & Total & 119.738 & 60 & & & \\
\hline \multirow[t]{3}{*}{ Do you support the tax lavi } & Between Groups & .000 & 4 & \multirow{3}{*}{$\begin{array}{l}.000 \\
.000\end{array}$} & & \\
\hline & Within Groups & .000 & 56 & & & \\
\hline & Total & .000 & 60 & & & \\
\hline \multirow{3}{*}{$\begin{array}{l}\text { Have you ever been in a } \\
\text { situation where you have } \\
\text { resorted to tax evasion }\end{array}$} & Between Groups & .000 & 4 & \multirow{3}{*}{$\begin{array}{l}.000 \\
.000\end{array}$} & & \\
\hline & Within Groups & .000 & 56 & & & \\
\hline & Total & .000 & 60 & & & \\
\hline
\end{tabular}

The above table shows the results of the ANOVA test and whether there is a statistical difference between the group means. The group "not having governmental services for VAT taken" has a significance value of 0.008 . Since this value is lower than 0.05 , there is a statistically significant difference between this group and the group of "it is acceptable to avoid tax payment as long as it is within a legal loophole". The group "the economic condition" has a significance value of 0.054 . Since this value is greater than 0.05 , there is no statistically significant value in this group. The rest of the tested groups also have no statistical significance values. 


\subsubsection{Correlation Matrix}

Table (15) Correlation matrix

\begin{tabular}{|c|c|c|c|c|c|c|c|c|c|}
\hline \multicolumn{10}{|c|}{ Correlations } \\
\hline & & $\begin{array}{l}\text { the increse } \\
\text { rate of VAT }\end{array}$ & $\begin{array}{l}\text { not having } \\
\text { governmental } \\
\text { services for } \\
\text { the VAT taken }\end{array}$ & $\begin{array}{l}\text { the economic } \\
\text { condition for } \\
\text { the VAT payee }\end{array}$ & $\begin{array}{c}\text { it is } \\
\text { acceptable to } \\
\text { avoid } \\
\text { payment as } \\
\text { long as it is } \\
\text { with small } \\
\text { amount of } \\
\text { evasion }\end{array}$ & $\begin{array}{l}\text { tx evasion is } \\
\text { acceptable as } \\
\text { long as it } \\
\text { within legal } \\
\text { loopwhole }\end{array}$ & $\begin{array}{l}\text { i dont mind } \\
\text { dispencing } \\
\text { the bill in } \\
\text { return for } 15 \% \\
\text { VAT } \\
\text { deduction in } \\
\text { the amount }\end{array}$ & $\begin{array}{l}\text { Do you } \\
\text { support the } \\
\text { tax law }\end{array}$ & $\begin{array}{l}\text { Have you ever } \\
\text { been in a } \\
\text { situation } \\
\text { where you } \\
\text { have resorted } \\
\text { to tax evasion }\end{array}$ \\
\hline \multirow[t]{3}{*}{ the increse rate of VAT } & Pearson Correlation & 1 & $.478^{\prime \prime \prime}$ & $.281^{n}$ & .211 & $.409^{\prime \prime}$ & $299^{x}$ & $\circ$ & ${ }^{\circ}$ \\
\hline & Sig. (2-tailed) & & .000 & .028 & .103 & .001 & .019 & & . \\
\hline & $\mathrm{N}$ & 61 & 61 & 61 & 61 & 61 & 61 & 61 & 61 \\
\hline \multirow{3}{*}{$\begin{array}{l}\text { not having governmental } \\
\text { services for the VAT taken }\end{array}$} & Pearson Correlation & $.478^{\text {nt }}$ & 1 & $.377^{* 1}$ & .204 & $417^{m+1}$ & $.524^{\pi n}$ & $\therefore$ & $\therefore$ \\
\hline & Sig. (2-tailed) & .000 & & .003 & .114 & .001 & .000 & & \\
\hline & $\mathrm{N}$ & 61 & 61 & 61 & 61 & 61 & 61 & 61 & 61 \\
\hline \multirow{3}{*}{$\begin{array}{l}\text { the economic condition } \\
\text { for the VAT payee }\end{array}$} & Pearson Correlation & $281^{x}$ & $.377^{* 1}$ & 1 & $417^{\prime \prime \prime}$ & $.306^{n}$ & .220 & $\therefore$ & $\therefore$ \\
\hline & Sig. (2-tailed) & .028 & .003 & & .001 & .016 & .089 & & . \\
\hline & $\mathrm{N}$ & 61 & 61 & 61 & 61 & 61 & 61 & 61 & 61 \\
\hline \multirow{3}{*}{$\begin{array}{l}\text { it is acceptable to avoid } \\
\text { payment as long as it is } \\
\text { with small amount of } \\
\text { evasion }\end{array}$} & Pearson Correlation & .211 & .204 & $417^{m}$ & 1 & $644^{m}$ & $.382^{\prime \prime \prime}$ & $\stackrel{\circ}{\circ}$ & $\therefore$ \\
\hline & Sig. (2-tailed) & .103 & .114 & .001 & & .000 & .002 & & . \\
\hline & $\mathrm{N}$ & 61 & 61 & 61 & 61 & 61 & 61 & 61 & 61 \\
\hline \multirow{3}{*}{$\begin{array}{l}\text { tx evasion is acceptable } \\
\text { as long as it within legal } \\
\text { loopwhole }\end{array}$} & Pearson Correlation & $.409^{\prime \prime}$ & $.417^{m}$ & $.306^{*}$ & $644^{\prime \prime}$ & 1 & $.569^{\prime \prime}$ & $\therefore$ & $\therefore$ \\
\hline & Sig. (2-tailed) & .001 & .001 & .016 & .000 & & .000 & & . \\
\hline & $\mathrm{N}$ & 61 & 61 & 61 & 61 & 61 & 61 & 61 & 61 \\
\hline \multirow{3}{*}{$\begin{array}{l}\text { i dont mind dispencing } \\
\text { the bill in return for } 15 \% \\
\text { VAT deduction in the } \\
\text { amount }\end{array}$} & Pearson Correlation & $299^{*}$ & $.524^{\prime \prime}$ & .220 & $382^{m+1}$ & $.569^{\prime \prime}$ & 1 & $\mathrm{c}$ & 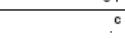 \\
\hline & Sig. (2-tailed) & .019 & .000 & .089 & .002 & .000 & & & . \\
\hline & $\mathrm{N}$ & 61 & 61 & 61 & 61 & 61 & 61 & 61 & 61 \\
\hline \multirow{3}{*}{$\begin{array}{l}\text { Do you support the tax } \\
\text { law }\end{array}$} & Pearson Correlation & $\therefore$ & $\therefore$ & ${ }^{\circ}$ & 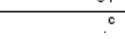 & 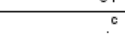 & c & 8 & ${ }^{\circ}$ \\
\hline & Sig. (2-tailed) & & & & & & & & \\
\hline & $\mathrm{N}$ & 61 & 61 & 61 & 61 & 61 & 61 & 61 & 61 \\
\hline
\end{tabular}

The above table shows the correlation matrix between selected variables. Pearson Correlation was selected since it indicates the relationship between groups. The values range from 1 to -1 , which represents a strong positive or strong negative correlation (Schober et al., 2018). Hypothesis 1 shows the relationship between morality or perception of fairness and tax evasion. The variable "it is acceptable to avoid payment as long as it is within legal loophole" has strong correlations of $0.409,0.417,0.306,0.644$, and 0.569 . It does not correlate with variables of "supporting tax law" and "evading tax". This is because these variables have the same value of 2 .

Table (16) Descriptive of tax evasion if legal or small

\begin{tabular}{|l|r|r|r|r|}
\hline & $\mathrm{N}$ & Mean & Std. Deviation & Std. Error Mean \\
\hline $\begin{array}{l}\text { it is acceptable to avoid } \\
\text { payment as long as it is with } \\
\text { small amount of evasion } \\
\text { txevasion is acceptable as } \\
\text { long as it within legal } \\
\text { loophole }\end{array}$ & 61 & 1.69 & 1.057 & -135 \\
\hline
\end{tabular}

The above table shows that the mean of the selected groups is 1.69 and 2.31 . Hence, the majority of the participants disagree with the idea of tax evasion even when it is within a legal loophole or small. 
Thus, the H1 that implies that the level of morality and perception of fairness in the individual norm play an important role in tax evasion is supported because the majority of the participants disagreed on evading tax even when there was a legal loophole. Additionally, The ANOVA test has shown that there are no statistical differences between the majorities of the selected groups. Meanwhile, the correlation matrix shows that there is a strong correlation between most of the variables. The only variables that do not correlate are "supporting tax law" and "evading tax". All the participants do not evade tax and positively support tax law. Therefore, individuals avoid tax evasion due to morality standings.

Table (17) The effect of the results on the hypothesis

\begin{tabular}{|l|l|}
\hline Hypothesis & Result \\
\hline $\begin{array}{l}\text { H1: The level of morality and perception of fairness in the individual } \\
\text { norm play an important role in tax evasion. }\end{array}$ & Supported \\
\hline $\begin{array}{l}\text { H2: The complexity of regulation or the lack of individual knowledge } \\
\text { toward the importance of the VAT on the national economy. }\end{array}$ & Supported \\
\hline
\end{tabular}

The first hypothesis confirms that the level of morality and perception of fairness in the individual norm affects tax evasion. From table 10, most of the respondents disagree with evading tax even when it is small or has a legal loophole. Apart from this, from the ANOVA and correlation matrix, all the participants do not evade tax law. They also fully support the implementation of tax law. Their perception of morality disregards the idea of tax evasion even when it has little implications. Hence, their view on morality significantly affects their perception of tax evasion.

The second hypothesis shows the relationship between lack of individual knowledge or complexity of tax regulation and the importance of VAT on the economy. That hypothesis is supported because the respondents have an overall medium to low level of knowledge regarding tax law. Moreover, all respondents have never attended any tax implementation seminars. Regardless of having limited knowledge, the participants still acknowledge the impact of taxes on the economy. For example, some of them acknowledge that the tax should be slightly decreased. 
The government should make an effort in educating its citizens regarding taxes. When citizens know more about taxes, they will appreciate the role that taxes play in developing the economy.

\section{Conclusion:}

Tax plays an important role in our community, as it helps the government to provide further facilities that could uplift the country and community. The Saudi government had faced a lot of resistance in applying tax rules, which lead to tax evasion and avoidance by some individuals. This study is focusing on finding the relationship between morality and understanding tax rules with tax evasion and why individuals are keener to engage in such acts.

The study had focused on testing two main hypotheses to see the relationship between two main groups (morality and understanding) to tax evasion. As it showed the hypothesis was supported by the data collected. For instance, in H1: the level of morality do plays a massive role in the perception of tax evasion. Despite that, nearly $90 \%$ of the participant had not engaged in tax evasion, yet nearly all had agreed to spare the invoice in exchange for a $15 \%$ decrease in the total amount.

Furthermore, in H2: despite the massive awareness seminars that are being conducted by ZATCA, the level of awareness the individuals have is low to medium level when it comes to understanding the tax rules and regulations. Due to the resistance behavior, individuals are constrained from having a proper exposure to tax rules and regulations which caused the difficulties that some individuals are facing in applying or following tax legislation. Also, some responses reflected that misunderstanding and the complexity rely not on the rules and regulation rather on the benefits that they would have from paying taxes. Participants believe that they are entitled to having and exposure to where the taxes are being spent and having more facilities that would help them in their daily life in exchange for paying taxes. 


\section{References:}

1. Overview of Saudi Arabia's tax regulations. (2021, January 9). Oxford Business Group. https://oxfordbusinessgroup.com/overview/steady-evolution-updatedregulations-are-put-place-basics-remain-unchanged

2. ZATCA. (20147-11). Kingdom of Saudi Arabia VAT MANUAL (version 1). VAT. https://zatca.gov.sa/en/RulesRegulations/VAT/Documents/VAT_Manual_English_1 6_Nov.pdf

3. Taxes on goods and services (\% value-added of industry and services) - Saudi Arabia | Data. (2010). [Dataset].

https://data.worldbank.org/indicator/GC.TAX.GSRV.VA.ZS?locations=SA\&most_re cent_year_desc=false

4. Opreţ, L. A., Turcaş, F. M., Dumiter, F. C., \& Brezeanu, P. (2017). Tax evasion between fraud and legality. Studia Universitatis „Vasile Goldis” Arad - Economics Series, 27(4), 1-11. https://doi.org/10.1515/sues-2017-0013

5. Litina, A., \& Palivos, T. (2016). Corruption, tax evasion, and social values. Journal of Economic Behavior \& Organization, 124, 164-177. https://doi.org/10.1016/j.jebo.2015.09.017

6. Amoedo, A., Martnez-Costa, M. D. P., \& Moreno, E. (2009). An analysis of the communication strategies of Spanish commercial music networks on the web: http://los40.com, http://los40principales.com, http://cadena100.es, http://europafm.es, and http://kissfm.es. Radio Journal: International Studies in Broadcast \& Audio Media, 6(1), 5-20. https://doi.org/10.1386/rajo.6.1.5_4

7. Almansoori, D. H. (2019). TAX EVASION AND ITS EFFECT ON CRIMINAL LIABILITY UNDER UAE TAX LAW. Sharia \& Law Is the Property of United Arab Emirates University, year 33(79), 33-72.

8. Hoekstra, R., Vugteveen, J., Warrens, M. J., \& Kruyen, P. M. (2019). An empirical analysis of alleged misunderstandings of coefficient alpha. International Journal of Social Research Methodology, 22(4), 351-364. https://doi.org/10.1080/13645579.2018.1547523 
9. Kaltenbach, H. M. (2021). Comparing More Than Two Groups: One-Way ANOVA. Statistical Design and Analysis of Biological Experiments, 69-96. https://doi.org/10.1007/978-3-030-69641-2_4

10. Okagbue, H. I., Oguntunde, P. E., Obasi, E. C., \& Akhmetshin, E. M. (2021). Trends and usage pattern of SPSS and Minitab Software in Scientific research. Journal of Physics: Conference Series, 1734(1), 012017. https://IOP Publishing. 10.1088/1742$6596 / 1734 / 1 / 012017$

11. Ross, A., \& Willson, V. L. (2017). One-sample T-test. Basic and Advanced Statistical Tests, 9-12.

https://brill.com/downloadpdf/book/edcoll/9789463510868/BP000003.pdf

12. Schober, P., Boer, C., \& Schwarte, L. A. (2018). Correlation coefficients: appropriate use and interpretation. Anesthesia \& Analgesia, 126(5), 1763-1768.

https://doi.org/10.1213/ANE.0000000000002864

Copyright (C) 2021 Daniah Tariq H. Raqaban, AJRSP. This is an Open-Access Article Distributed under the Terms of the Creative Commons Attribution License (CC BY NC)

Doi: doi.org/10.52132/Ajrsp.e.2021.32.3 